\title{
Clinical importance of P53 and P21 determination as a biomarkers in bladder cancer and bilharzial patients
}

\author{
Wafaa Abd-Allah* Sohair A Hassan**, Faten E Hafez and*** \\ Hafez Faruk*. \\ * Cancer Biology Department, National Cancer Institute, Cairo, Egypt. \\ ** Medicinal Chemistry Department, National Research Center, Cairo, Egypt. \\ ***Clinical Pathology Department, National Cancer Institute, Cairo, Egypt.
}

\begin{abstract}
The present study was made to shed more light on the clinical importance of early detection of bladder cancer using p53 and p21 mutant proteins as a biomarkers using simple, applicable ELISA techniques. Serum samples were collected from 70 patients, the first group included 50 bladder cancer patients, the second included 20 bilharzial patients, while the third group consisted of 20 healthy individuals used as control. P53 wild and mutant types showed significant changes $(p<0.02$ and $<0.007$,respectively $)$ in bilharzial patients. Also they showed significant changes in bladder cancer patients with $(+\mathrm{ve})$ lymph node $(\mathrm{p}<0.02$ and $\mathrm{p}<0.01$, respectively) when compared to control as well as it showed great differences between low and high grade $(\mathrm{p}<0.01$ and $\mathrm{p}<0.001)$ for wild and mutant type. Moreover $\mathrm{p} 53$ showed higher sensitivity levels for mutant and wild type in both bilharzial 19.5, 31.2 compared to 23.9 and $35.9 \%$, respectively in bladder cancer one. P21 mutated amino acids were proved to be of significant values in bladder cancer group $(\mathrm{p}<0.001)$ compared to bilharzial group. The $\mathrm{p} 21$ mutated amino acids showed a correlation with different histological grades for bladder patients, while ARG12 and ASP13 were highly related to bladder cancer with bilharzial history with the notion that ASP13 achieved high sensitivity level to bladder cancer group $91 \%$ and $83 \%$ for those of bladder cancer with bilharzial history .In conclusion the results of the present study revealed that determination of both $\mathrm{p} 53$ and $\mathrm{p} 21$ are of great value in the early detection and follow up of bladder cancer patients and screening for risky bilharzial ones .
\end{abstract}

\section{Introduction}

Bladder cancer represents a main health problem in Egypt. Its a major urological disease and accounted for $30.3 \%$ of total malignancies according to the registry of National Cancer Institute ( NCI ) Cairo University in 1990 (Mokhtar, 1991). In fact bladder cancer is uncommon below the age of 40 years ( Samuel and Sonny, 1992). In younger ages as they exposed to bilhazial infection the incidence of bilharzial bladder cancer is remarkably higher when compared to non-bilharzial series (Payne, 1959). The incidence of bladder cancer increases with age reaching a peak between 50 to 60 years old ( El-Bolkainy et al., 1972, Fitzpatrick and Reda, 1986). Bladder cancer is five times more frequent in men than in women, a different causes that is not entirely explained by differences in cigarette smoking or occupatio-nal exposure ( Hartge et al., 1990).

In Egypt, the male incidence of bladder cancer is higher (Mokhtar, 1991) due to frequent field exposure and bilharzial infestation among men. Considerable evidence suggests that schistosomiasis plays an important role in the development of bladder cancer in Egypt and other countries where infection with the parasite is epidemic (El-Bolkainy, 1998). Several hypothesis have been proposed to explain the etiological roles of schistosomal infection in the development of bladder cancer. Among these roles only two are strongly contributing in the development of the tumor. The first one is increasement of 
inflammatory and regenerative process in the bladder of these patients. The second factor is the increase of cell proliferation over long periods which provide more opportunities for spontaneous genetic error that ultimately can lead to a higher incidence of cancer whether of the bladder or other tissue (Cohen, 1991).

The pathological features of bladder cancer associated to bilharziasis are different than those in regions where infection with the parasite is not endemic. The most striking difference is the high incidence of squamous cell carcinoma (SCC) in the bilharzial bladder patients diagnosed with bilharzial related cancer. They are generally younger and squamous cell carcinoma tends to recur early locally but metastasize later (Osman et al., 1997). Gene mutations were detected in a high proportion of primary invasive bladder cancer (Sidransky et al.,1991).

In recent years, significant information has been accumulated on molecular alterations that takes place during development of bladder cancer , p53 mutation was frequent greater than $70 \%$ whereas H-ras mutation was infrequently about $10 \%$ (Gen et al.,2001). Several gene products are involved in regulation of cell proliferation. The protein p53 is functionally closely related to cell proliferation. It regulates the expression of other genes related to cell cycle. The wild $\mathrm{p} 53$ protein is localized and acts within the nucleus with DNA binding properties and potent transcriptional activation. Normal cells contain low concentration of wild type p53 protein as it has a very short half life time. The precise mechanism by which p53 functions has not been defined, however, several observations include regulation of the cell cycle and suppression of cell proliferation; cellular response to DNA damage; initiation of DNA repair and replication; induction of apoptosis and promotion of cell differentiation were reported (Tenti et al., 1995). The negative regulatory effect on the cell cycle allows for cellular differe-ntiation and block at G1 phase (Kroemer, 1997). There are four closely related human ras proto-oncogenes forms which identified as ( $\mathrm{H}-\mathrm{K} 4 \mathrm{~A}-\mathrm{K} 4 \mathrm{~B}$ and $\mathrm{N}$ ras ). They encode small guanine nucleotide binding proteins (p21 ras) with intrinsic guanosine triphosphatase (GTPase) activity that are involved in cellular signal transduction.

P21 protein is located on the inner or cytoplasmic side of plasma membrane of most cell types and contain 188-189 amino acids. It acts as a signal transducer from membrane receptors to the nucleus, thus regulates growth and differentiation. The mutant forms of ras oncogenes can transform cells by specific point mutations resulting in amino acid substitutions at codons 12,13 and 61 of the p21 ( Czerniak et al., 1992). Overexpression of $\mathrm{p} 21$ protein as the result of $\mathrm{H}$ - ras oncogenic activation were identified in different tumors including bladder neoplasms (Gen et al., 2000).

In bladder cancer, several attempt have been made to assess the effect of p53 and $\mathrm{p} 21$ mutations on diagnosis, prognosis and response to therapy. The present study was designed to identify wild and mutant p53 protein expression and point mutation of amino acids substitutions of $\mathrm{p} 21$ proteins as a diagnostic tools in a trial to employ them as an early detection biomarkers in bladder cancer patients and bilharzial patients as a high risky models.

\section{Material and Methods}

Serum samples were obtained from : 1- Egyptian bladder cancer patients with histopathologically verified bladder cancer (50) from inpatients of National Cancer Institute in period from (May 2001 to Dec 2001 ). 2- Egyptian bliharzial patients ( 20 ) from outpatients of Tropical Medicine Institute at the same period . Their infestation was confirmed by detection of bliharzial antibodies in their serum. 3Apparently 20 healthy individuals used as control.

\section{Measurement of P53-autoantibody by ELISA}

Measurement of P53 wild and mutant type in the serum samples was carried out using p53- autoantibody ELISA kit according to the manufacturers instructions that produced by Oncogene science USA using both mouse monoclonal and rabbit polyclonal antibodies. Briefly, using a microtiter 
plate format ,diluted serum calibrators (in duplicates) and controls were added to separate wells that were precoated with recombinant human wild or mutant type p53 proteins. After overnight incubation at $4^{\circ} \mathrm{C}$ and adequate washing a p53 reporter antibody was added into the control , standard and sample wells then incubated for $2 \mathrm{hrs}$ at room temperature. The wells were washed 4 times again and incubated for $1 \mathrm{hr}$ at room temperature after addition of peroxidase conjugate and washed 4 times, then substrate orthophen-yldiamine OPD was added and incubated for 30 minutes in dark at room temperature. The wells were read within 30 minutes after adding stop solution by using ELISA reader at dual wavelengths (405/ $490 \mathrm{~nm})$.

\section{Measurement of p21-autoantibody by ELISA:}

P21 the Oncogene science ras mutation assay is a non - isotopic qualitative immunoassay for the in vitro identification of four mutant forms of P21 ras in tissue extracts, cell culture extracts and fluids. The kit used broadly reactive anti P21 ras rabbit polyclonal antibodies each recognize a specific mutated form of $\mathrm{P} 21$, either Arg 12 P21, Val 12 P21, Asp 12 P21 or Asp 13 P21 thus allowing the identifycation of the particular mutation present in a sample. Control cell lysates containing known P21 ras mutation are provided in the kit as a positive and negative samples to confirm specificity of the assay .

\section{Statistical Analysis System ( SAS )}

Analysis of Variance ( ANOVA) is an extension to the student's test used when comparing more than two groups .Pair wise comparisons between the groups were performed using Scheffes multiple comparisons test. Associations between variables were evaluated with chi -squared tests .

\section{Results}

Seventy patients were considered as suitable for inclusion in the study. Twenty bilharzial and fifty bladder cancer patients were compared with twenty normal individuals. Serum level of P53 protein in bilharzial patients showed significant value in both wild $(\mathrm{p}<0.02)$ and mutant $(p<0.007)$ type of protein whereas bladder cancer patients recorded higher values more than those of bilharzial patients in both wild $(\mathrm{p}<0.003)$ and mutant $(\mathrm{p}<0.001)$ type of protein (Table 1 ). Bladder cancer patients were classified according to sex, bilharzial history, histopathological types, lymph node involvements and different grades (Table 2). The results revealed that bladder cancer patients with lymph nodes positive had significant value when compared with negative lymph nodes patients in both wild $(\mathrm{p}<0.02)$ and mutant $(\mathrm{p}<0.01)$ proteins. Also, serum level of P53 of bladder cancer patients showed significant difference between different grades in both wild ( $\mathrm{p}<$ $0.01)$ and mutant $(\mathrm{p}<0.001)$ protein. Only mutant p53 protein had slightly significant difference $(p<0.03)$ between male and female. Other values in table 2 were irrelevant.

Table 3 showed wild p53 sensitivity $19.5 \%$ in bilharzial patients and $31.2 \%$ in bladder cancer patients whereas mutant p53 showed $23.9 \%$ in bilharizial and 35.9 in bladder cancer patients at the same point of specificity (95\%). Other values of sensitivity and specificity at different cut -off values were reported in table (3).

P21 protein was represented by four types of amino acid mutations ARG12, VAL12, ASP12 and ASP13 (Table- 4) showed that amino acid mutation had a significant values in bilharzial and bladder cancer patients $(\mathrm{P}<0.001)$ compared to control. When using scheffes test, bladder cancer patients showed also significant values in all types of mutations while bilharzial group patients showed low significant value in ARG12 $(\mathrm{p}<0.03)$ and ASP13 ( $\mathrm{p}<0.04)$. There was no correlation's for mutated amino acids P21 with sex or with histopathological types. On the other hand the results revealed that there were significant difference between positive and negative lymph nodes bladder cancer patients in three amino acid mutations ARG12 $(\mathrm{p}=<0.003)$, VAL12 $(\mathrm{p}<0.001)$ and ASP13 ( $\mathrm{p}<0.04)$ while ASP12 recorded no significant result. The bladder cancer patients with bilharzial history recorded 
significant values in $\operatorname{ARG12}(p<0.001)$ and ASP13 ( $\mathrm{p},<0.004)$ mutated amino acid (Table 5), whereas VAL12 and ASP12 showed irrelevant ones. Moreover strong correlation was seen between different grades and the four types of mutated amino acid ARG12 ( $\mathrm{p}<0,04,0.001)$, VAL12 ( $\mathrm{p}<$ $0.01,0.001)$, ASP12 ( $<<0.03,0.001)$ and ASP13 ( $\mathrm{p}<0.04,0.002)$, respectively in grade II and III in relation to grade I . Sensitivity and specificity of the mutated p21 amino acids were represented by ROC curves (Fig 1a,b) discriminating bilharzial and bladder patients from normal control. Bilharzial patients recorded sensitivity levels of ARG12 (67\%), VAL12 (78\%), ASP12 $(83 \%)$ and $(78 \%)$ for ASP13, while bladder cancer patients revealed sensitivity levels differentiation of bilharzial group and bladder cancer one as represented by ROC curve (Fig $1 c)$.

Table (1) : Comparison between wild and mutant P53 proteins in the serum of bilharzial and bladder cancer patients

\begin{tabular}{|c|c|c|c|c|}
\hline Group & Wild P53 & P.value & Mutant P53 & P. value \\
\hline Control (20)* & $1295 \pm 224 * *$ & & $0.28 \pm 0.05$ & \\
& $(929-1652)^{* * *}$ & & $(0.20-0.4)$ & \\
\hline Bilharzial (20) & $984 \pm 290$ & $\mathrm{P} \leq 0.02$ & $0.32 \pm 0.03$ & $\mathrm{P} \leq 0.007$ \\
& $(400-1520$ & & $(0.20-0.52)$ & \\
\hline Bladder cancer (50) & $915 \pm 314$ & $\mathrm{P} \leq 0.003$ & $0.48 \pm 0.19$ & \\
& $(325-1500)$ & & $(0.25-1.20)$ & $\mathrm{P} \leq 0.001$ \\
\hline
\end{tabular}

\section{Lagends}

* Number of individuals in each group

** Mean \pm SD

*** The lowest and highest values obtained

$P$. value $\leq 0.05$ is considered significant

Wild and mutant P53 is represented as pg/L and $\mathrm{ng} / \mathrm{L}$, respectively.

Table (2): Comparison between wild and mutant P53 types in studied groups of bladder cancer patients.

\begin{tabular}{|c|c|c|c|c|c|}
\hline \multirow[t]{2}{*}{ Bladder Cancer Patients } & \multirow[t]{2}{*}{ Number } & \multicolumn{2}{|c|}{ Wild P53 } & \multicolumn{2}{|c|}{ Mutant P53 } \\
\hline & & Mean \pm SD & P. value & Mean \pm SD & P. value \\
\hline $\begin{array}{c}\text { Sex } \\
\text { Female }\end{array}$ & 12 & $910 \pm 220$ & & $046 \pm 0.1$ & \\
\hline & 38 & & 0.085 & & 0.03 \\
\hline $\begin{array}{l}\text { Bilharzial } \\
+ \text { ve }\end{array}$ & 36 & $920 \pm 241$ & & $0.52 \pm 0.19$ & \\
\hline- ve & 14 & $928 \pm 243$ & & $0.48 \pm 0.20$ & \\
\hline $\begin{array}{c}\text { Histopathological } \\
\text { Type }\end{array}$ & & & & & \\
\hline T.C.C. & 27 & $939 \pm 218$ & & $0.51 \pm 0.22$ & \\
\hline S.C.S. & 23 & $928 \pm 228$ & & $0.49 \pm 0.21$ & \\
\hline $\begin{array}{l}\text { Lymph node } \\
+ \text { ve }\end{array}$ & 25 & $952 \pm 260$ & & $0.67 \pm 0.24$ & \\
\hline - ve & 25 & $1012 \pm 217$ & & $0.42 \pm 0.12$ & \\
\hline $\begin{array}{l}\text { Grades } \\
\text { I }\end{array}$ & 12 & $465 \pm 222$ & & $0.38 \pm 0.09$ & \\
\hline II & 23 & $912 \pm 198$ & 0.01 & $0.43 \pm 0.12$ & 0.001 \\
\hline III & 15 & $720 \pm 168$ & 0.01 & $0.69 \pm 0.22$ & 0.001 \\
\hline
\end{tabular}

$\mathrm{P} \leq 0.05$ is considered significant . 
Grade II and III were compared to grade I.

Table (3) : Sensitivty and specificity of wild and mutant types p53 in bilharzial and bladder cancer patients

\begin{tabular}{|c|c|c|c|c|}
\hline Parameter & Groups & Cut off value & Sensitivity\% & Specificity\% \\
\hline \multirow{10}{*}{$\begin{array}{l}\text { Wild } \\
\text { P } 53\end{array}$} & & 1400 & 17.4 & 100 \\
\hline & & 1410 & 18.2 & 97 \\
\hline & Bilharzial & 1420 & 19.5 & 95 \\
\hline & $\mathrm{N}=20$ & 1430 & 20.6 & 90 \\
\hline & & 1440 & 22.0 & 85 \\
\hline & & 1520 & 27.5 & 100 \\
\hline & & 1530 & 29.4 & 97 \\
\hline & Bladder cancer & 1540 & 31.2 & 95 \\
\hline & $\mathrm{N}=50$ & 1550 & 33.0 & 90 \\
\hline & & 1560 & 35.5 & 85 \\
\hline \multirow{10}{*}{$\begin{array}{l}\text { Mutant } \\
\text { P } 53\end{array}$} & & 0.27 & 23.5 & 100 \\
\hline & & 0.32 & 23.7 & 97 \\
\hline & Bilharzial & 0.38 & 23.9 & 95 \\
\hline & $\mathrm{N}=20$ & 0.43 & 24.2 & 90 \\
\hline & & 0.48 & 24.4 & 85 \\
\hline & & 0.56 & 31.7 & 100 \\
\hline & Bladder cancer & 0.61 & 33.5 & 97 \\
\hline & $\mathrm{N}=50$ & 0.66 & 35.9 & 95 \\
\hline & & 0.71 & 38.5 & 90 \\
\hline & & 0.76 & 41.6 & 85 \\
\hline
\end{tabular}

Table (4): Comparisons between different P21 amino acids in patients of bilharzial and bladder cancer patients

\begin{tabular}{|l|l|l|l|l|l|}
\hline Group & $\begin{array}{l}\text { Control } \\
(20)^{*}\end{array}$ & $\begin{array}{l}\text { Bilharzial } \\
(20)\end{array}$ & P.value & $\begin{array}{l}\text { Bladder cancer } \\
(50)\end{array}$ & P.value \\
\hline ARG 12 & $0.314 \mathrm{~b} \pm 0.305^{* *}$ & $0.431 \mathrm{~b} \pm 0.290$ & 0.03 & $1.291 \mathrm{a} \pm 0.926$ & $<0.001$ \\
\hline VAL 12 & $0.336 \mathrm{~b} \pm 0.277$ & $0.709 \mathrm{a} \pm 0.427$ & 0.001 & $1.761 \mathrm{a} \pm 0.995$ & $<0.001$ \\
\hline ASP 12 & $0.285 \mathrm{~b} \pm 0.307$ & $0.743 \mathrm{a} \pm 0.546$ & 0.001 & $1.931 \mathrm{a} \pm 0.750$ & $<0.001$ \\
\hline ASP 13 & $0.184 \mathrm{~b} \pm 0.233$ & $0.325 \mathrm{~b} \pm 0.244$ & 0.04 & $0.930 \mathrm{a} \pm 0.672$ & $<0.001$ \\
\hline
\end{tabular}

\section{Lagends}

* Number of individuals in each group

** Mean \pm SD

$P$. value $\leq 0.05$ is considered significant

No significant difference between groups sharing same letters. 
Table (5):Comparison between different constituents of P21 mutated amino acids in bladder cancer patients.

\begin{tabular}{|c|c|c|c|c|c|c|c|c|}
\hline $\begin{array}{l}\text { Bladder Cancer } \\
\text { Patients }\end{array}$ & $\begin{array}{l}\text { ARG } 12 \\
\text { Mean } \pm \text { SD }\end{array}$ & $\begin{array}{l}\text { P- } \\
\text { Value }\end{array}$ & $\begin{array}{l}\text { VAL } 12 \\
\text { Mean } \\
\pm \text { SD }\end{array}$ & $\begin{array}{l}\mathrm{P}- \\
\text { Value }\end{array}$ & $\begin{array}{l}\text { ASP } 12 \\
\text { Mean } \pm \text { SD }\end{array}$ & $\begin{array}{l}\mathrm{P}- \\
\text { Value }\end{array}$ & $\begin{array}{l}\text { ASP } 13 \\
\text { Mean } \pm \text { SD }\end{array}$ & P-Value \\
\hline \multicolumn{9}{|l|}{ Sex } \\
\hline Female 12 & $1.1 \pm 0.4$ & \multirow[t]{2}{*}{0.96} & $1.5 \pm 0.8$ & \multirow[t]{2}{*}{0.20} & $2.2 \pm 0.6$ & \multirow[t]{2}{*}{0.15} & $0.96 \pm 0.5$ & \multirow[t]{2}{*}{0.57} \\
\hline Male 38 & $1.4 \pm 1.1$ & & $1.9 \pm 1.1$ & & $1.9 \pm 0.8$ & & $0.9 \pm 0.8$ & \\
\hline $\begin{array}{l}\text { Biharzial } \\
+ \text { ve } \quad 36\end{array}$ & \multicolumn{4}{|c|}{ Biharzial } & $2.0 \pm 0.8$ & \multirow[b]{2}{*}{0.210} & $1.2 \pm 0.7$ & \multirow[b]{2}{*}{0.004} \\
\hline - ve 14 & $0.8 \pm 0.4$ & 0.001 & $1.6 \pm 0.9$ & 0.140 & $1.8 \pm 0.7$ & & $0.7 \pm 0.5$ & \\
\hline \multicolumn{9}{|c|}{ Histopathological type } \\
\hline $\begin{array}{l}\text { T.C.C } 27 \\
\text { S.C.C } 23\end{array}$ & $\begin{array}{l}1.3 \pm 0.9 \\
1.3 \pm 1.0\end{array}$ & 0.14 & $\begin{array}{l}1.7 \pm 1.0 \\
1.9 \pm 1.0\end{array}$ & 0.35 & $\begin{array}{l}1.9 \pm 0.7 \\
2.0 \pm 0.9\end{array}$ & 0.65 & $\begin{array}{l}1.1 \pm 0.6 \\
0.8 \pm 0.8\end{array}$ & 0.07 \\
\hline \multicolumn{9}{|l|}{ Lymph node } \\
\hline $\begin{array}{l}+ \text { ve } 25 \\
- \text { ve } 25\end{array}$ & $\begin{array}{l}1.7 \pm 1.0 \\
1.0 \pm 0.7\end{array}$ & 0.003 & $\begin{array}{l}2.2 \pm 1.0 \\
1.4 \pm 0.7\end{array}$ & 0.001 & $\begin{array}{l}2.0 \pm 0.8 \\
1.8 \pm 0.7\end{array}$ & 0.26 & $\begin{array}{l}1.1 \pm 0.7 \\
0.8 \pm 0.6\end{array}$ & 0.04 \\
\hline \multicolumn{9}{|l|}{ Grades } \\
\hline $\begin{array}{ll}\text { I } & 12 \\
\text { II } & 23 \\
\text { III } & 15\end{array}$ & $\begin{array}{l}0.9 \mathrm{~b} \pm 0.9 \\
1.1 \mathrm{~b} \pm 0.7 \\
2.0 \mathrm{a} \pm 1.0\end{array}$ & $\begin{array}{l}0.04 \\
0.001\end{array}$ & $\begin{array}{l}1.0 \mathrm{~b} \pm 0.4 \\
1.6 \mathrm{~b} \pm 0.8 \\
2.6 \mathrm{a} \pm 1.0\end{array}$ & $\begin{array}{l}0.01 \\
0.001\end{array}$ & $\begin{array}{l}1.5 b \pm 0.5 \\
1.9 b \pm 0.8 \\
2.4 a \pm 0.7\end{array}$ & $\begin{array}{l}0.3 \\
0.001\end{array}$ & $\begin{array}{l}0.7 \pm 0.5 \\
0.9 b \pm 0.6 \\
1.4 a \pm 0.7\end{array}$ & $\begin{array}{l}0.04 \\
0.002\end{array}$ \\
\hline
\end{tabular}

$\mathrm{P}$-Value $\leq 0.05$ is considered significant

No significant difference between groups sharing same letters.
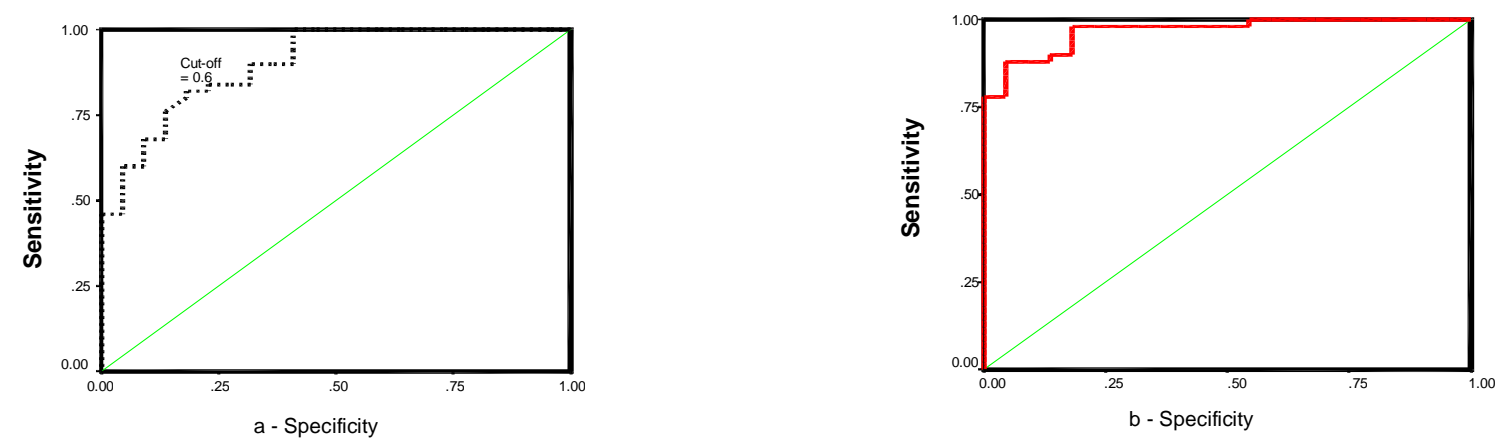

Fig 1

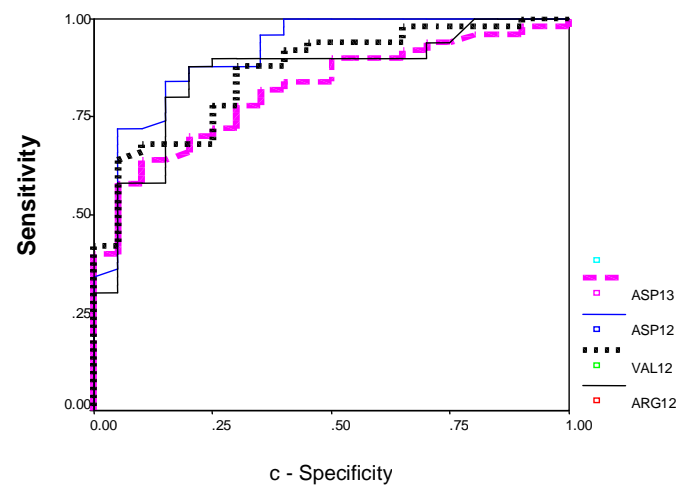

Fig 1 : Roc curves for differentiating
(a) Bilharzial form normal
(b) Bladder cancer patients form normal
(c) Bilharizal from bladder cancer patients 


\section{Discussion}

Methods of early detection of cancer are of great benefit to patients (Thomas, 1985) so, a golden dream for any oncologist is to diagnose cancer early by using simple and sensitive method (Pohi, 1990). Bladder tumors require surveillance: cystoscopy combined with urine cytology remains the eference examination. Several testes were designed for diagnosis and prognosis bladder tumors have been recently proposed in order to replace cytology and possibly reduce or even replace systematic cystoscopy (Irani, 1998).Functional proteome analysis of some oncogenic proteins as p21and tumor suppressor gene product proteins as $\mathrm{p} 53$ which involved in control of the cell cycle has identified as a biomerkers that are helpfull in early detection and diagnosis of bladder and other types of tumors (Orntoft and Wolf, 1998; Tanaka, et al., 1988).

In this study p53 and p21 proteins have been detected by a simple and reproducible procedure which may be of clinical importance in early detection of risky cases (bilharziasis) and in early diagnosis of bladder cancer. Wild and mutant p53 proteins were investigated, the two types showed significant values in each of bilharzial and bladder cancer patients. Although, mutant p53 proved to be with more significance in bilharzial group since it recorded $(\mathrm{p}<0.007)$ and $(\mathrm{p}<0.001)$ for bladder cancer one .This may be attributed to the stability and half-life time of p53 which may be very short in wild than in mutant type. In the serum p53 wild and mutant type appeared with no association with bilharzial bladder cancer or with any of histopathological classifications. The results seemed to be in agreement with those of Haitel et al., (2001) who reported previously that there was no association of p53 positivity with histological type and bilharzial history. Moreover , Mutant p53 protein recorded higher sensitivity level $(23.9 \& 35.9 \%)$ compared to wild p53 ( $19.5 \& 31.2 \%)$ in both bilharzial and bladder cancer groups which may be in accordance with the results of some studies (Moch, et al., 1993; Tenti, et al., 1995;
Kuczyk, et al., 1995 and Nakanishi, et al., 1996) which had been shown that p53 overexpression is associated with higher tumor grades and poor prognosis.

Mutations in ras genes resulting in substitutions of amino acids of ras gene product $\mathrm{p} 21$ protein are commonly found in human tumors (Gedde-Dahl et al., 1992). The four amino acid mutations ARG 12,VAL12, ASP12 and ASP13 of p21 protein were detected in bilharzial and bladder cancer. The VAL12 \& ASP12 mutations were 2 fold higher in bilharzial group and 6 fold higher in bladder cancer patients when compared with normal group. ARG12 showed 1.5 fold in bilharzial compared to 4 fold in bladder cancer patients, also ASP13 recorded 1.6 fold in bilharzial in comparison to 5 fold in bladder cancer patients. Although the results revealed that the four mutations of $\mathrm{p} 21$ protein were detected in bilharzial and bladder cancer patients, VAL12 and ASP12 amino acids mutations had been proved to be of more significant values than ARG12\& ASP13. On the other side, no correlation was proved between the mutated p21 amino acids with each of sex or histological types of bladder cancer. Moreove neither ASP12 nor VAL12 mutated amino acids have shown a correlation to lymph node involvement or bladder cancer patients with bilharzial history .

On the other hand, the mutated amino acids showed relevant correlation with lymph node positive cases and bilharzial bladder cancer group except ASP12 \& VAL 12. They appeared to have no correlation with lymph node involvement or with bilharzial bladder cancer group. The mutated amino acids recorded a marked significant values specially in advanced grades for bladder cancer patients. In spite of all mutated amino acid showed high sensitivity in all studied groups, the results proved that ASP12 achieved the highest level of sensitivity (83\%) in bilharzial group compared to in bladder cancer one $(91 \%)$. So, the results of the present study revealed that combined determination of 
p53 and p21 mutant proteins may be of clinical value in early detection and diagnosis of bladder cancer. In conclusion a new non invasive method for the detection of urothelial carcinomase of the urinary bladder would open new possibilities in both the diagnosis and follow up of patients with bladder cancer,as well as in the screening of groups at risk for the development of malignancies.

\section{References}

1. Chen, M.G. and Kenneth, E.M.(1989): Progress in assessment of morbidety due to Schistosoma haematobium infection. A Revier of Recent Literature. Tropical Diseases Bulletin, 86 (4): R1-R36.

2. Cohen, S.M., Purtilo, D.T . and Ellwein L.B. (1991): Pivotal role of increased cell proliferation in human carcinogenesis. Med. Pathol, 4:371 -78.

3. Czerniak, B., Cohen, G. L., Etkind, P., Deitch, D., Simmons H., Herz., F., and Koss, L.G.(1992): Concurrent mutations of coding and regulatory sequences of the Haras gene in urinary bladder carcinomas. Hum. Pathol, 23: 1199-1204.

4. El-Bolkainy N.(1998): Cancer of urinary tract. In: Topographic Pathology of cancer. First edition. The National Cancer Institute. Cairo University, p. 53.

5. El-Bolkainy, M.N.; Ghoneim, M.A. and Mansour, M.A.(1972): Carcinoma of the bilharzial bladder in Egypt: Clinical and pathological feature. Brit. J. Urol, 44:56170.

6. Fitzpatrick, J.M. and Reda, M. (1986): Bladder carcinoma in patients 40 years old or less. J Urol., 135 1:53-4

7. Gedde-Dahl T, Spurkland A, Eriksen JA, Thorsby E, Gaudernack G. (1992): Memory $\mathrm{T}$ cells of a patient with follicular thyroid carcinoma recognize peptides derived from mutated p21 ras ( Gln- > Leu61)., Int Immunol, 4(11):1331-7.

8. Gen H, Yamamoto S, Morimura K, Min W, Mitsuhashi M, Murai T, Mori S, Hosono M, Oohara T, Makino S, Wanibuchi $H$ and Fukushima S. (2001): P53 and H-ras mutations and microsatellite instability in renal pelvic carcinomas., Jpn J Cancer Res, 92 (12):1278-83.

9. Haitel A., Posch B., El-Baz. M., Mokhtar A. A., Susani M., Ghoneim M.A. and Marberger M.(2001): Bilharzial related, organ confined, muscle invasive bladder cancer : Prognostic Value of Apoptosis
Markers, Proliferation Markers. J. Urology; 165: 1481-1487.

10. Hartge, P., Harvey E.B.; Marston, W. (1990): Unexplained excess risk of bladder cancer in men J.Natl. Cancer Inst, 82:163640 .

11. Irani, J. (1998): New diagnostic tests for urothelial of the bladder., Prog Urol, 8 (4): 481-46.

12. Kroemer, G. (1997): The proto-oncogene bcl-2 and its role in regulating apoptosis. Nat Med, 3 : $614-20$.

13. Kuczyk, M.A., Bokemeyer, C., Serth, J. et al (1995): P53 overexpression as a prognostic factor for advanced stage bladder cancer. Eur J Cancer, 31A (13-14): 2243-47.

14. Moch, A., Sauter, G., Moore, D. et al (1993): p53and erbB-2 protein over expression are associated with early invasion and metastasis in bladder cancer. Virch Arch A Pathol Anat Histopatho, 423(5):329-34

15. Mokhtar N.(1991): Cancer Pathology Registry (1995-1998), National Cancer Institute, Cairo University.Department of pathology ,p. 12.

16. Nakanishi, K., Kawai, T. and Torikata, C.(1996):Immunohisto-chemical evaluation of p53 oncoprotein in transitional cell carcinoma of the upper urinary tract. Hum Pathol, 27:1336-39.

17. Orntoft TF., Wolf.H (1998):Molecular alterations in bladder cancer., Urol Res, 26(4): 223-33.

18. Osman I., Scher H.I., Zhang Z.F., Pellicer I., Hamza R., Eissa S., Khaled H.and Cordon- Cardo C. (1997): Alterations affecting the p53 control pathway in bilharzial-related bladder cancer. Clin. Cancer Res, 3: (4) :531-36

19. Payne, P. (1959): Tumor of the bladder . DM. Wallace, (ed ), E. \& S Livingstone, Edinburgh and London, P. 285.

20. Pohi ,A.L. (1990): Tumor markers ,potential and limits of their application. The $2^{\text {nd }}$ international conference of The Egyptian Society of Tumor Markers Oncology, P: 86.

21. Samuel, M. and Sonny, L.(1992): Epidemiology and Etiology of cancer bladder, Urol Clin North Am; 19, (3 ): 421-28.

22. Sidransky,D.;Eschenbach,A.V.;TasiY.C.; Jones,P.; Summerhayes,I.; Marshall,F.; Paul, M.Green, P. Hamilton, S.R.; Frost, P. and Vogelstein, B.(1991): Identification of P53 gene mutations in bladder cancer 
and urine samples. Science (3),(5006), 252:607-09

23. Tanaka, T.; Slamon, D.G.; Shimoda, H.; Waki, C.; Kawaguchi, Y.; Tanaka, Y. and Ida, N.(1988): Expression of Ha-ras oncogene products in human neuroblastomas and the significant correlation with a patient's prognosis., Cancer Res , 48(4): 1030-1034.

24. Tenti, P., Zappatore, R., Romagnoli, S. et al (1995): P53 Overexpression and human papillomavirus infection in transitional cell carcinoma of the urinary bladder: correlation with histological parameters. J Pathol, 178: 65-70.

25. Thomas,P. (1985) : Molecular approaches to diagnosis of cancer, In The molecular basis of cancer. Walker, J.M and farmer P.B (eds): Croom Helm LTD, London . p. 201. 


\section{الأهمية الإكلينيكية لقياس كلاً من الـ ب53 ، ب 21 كدلالات حيوية

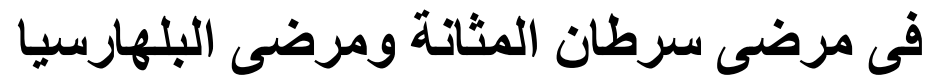

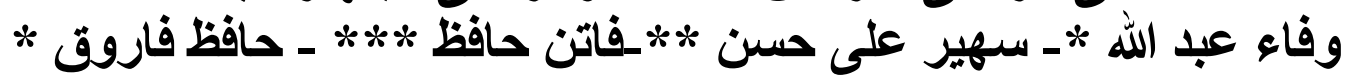

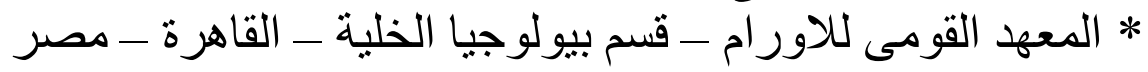

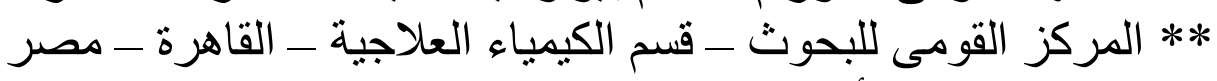

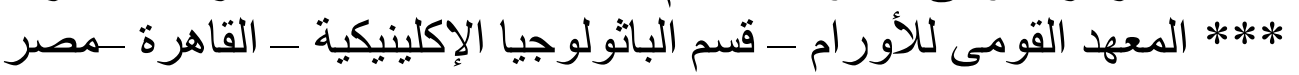

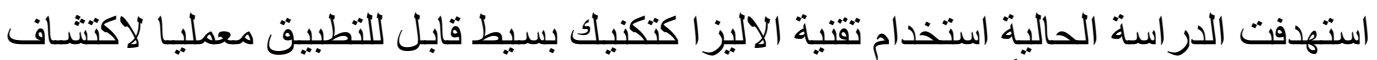

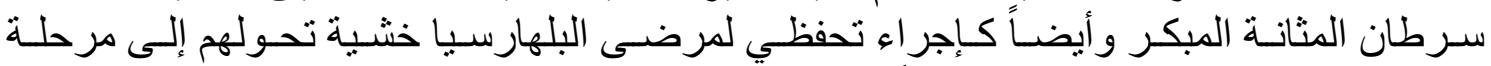

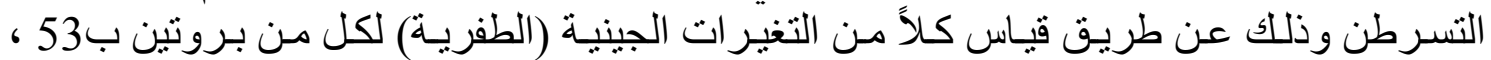

وقد اشتملت الدر اسة على 90 حالة قسمت كالاتى :

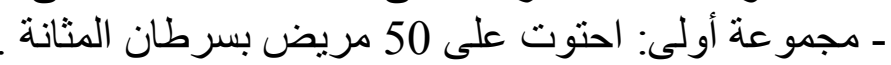

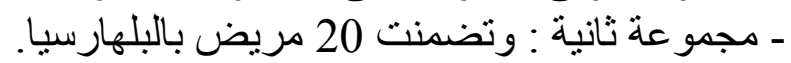

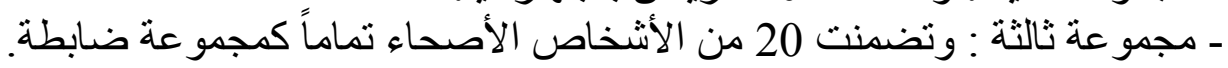

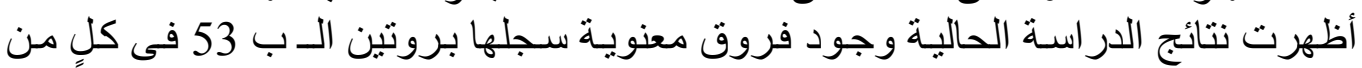

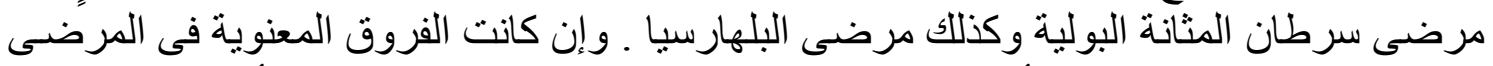

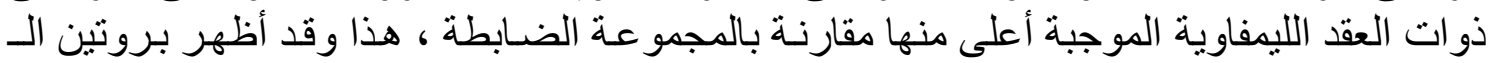

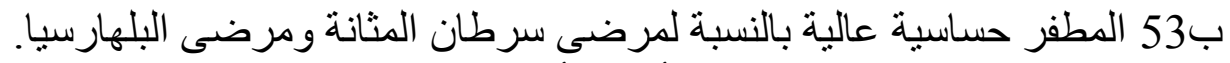

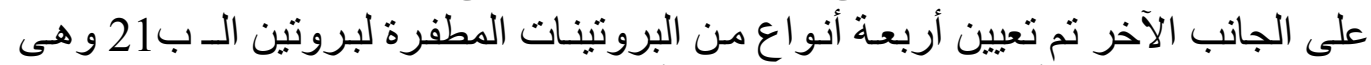

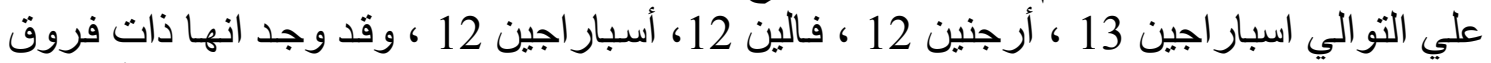

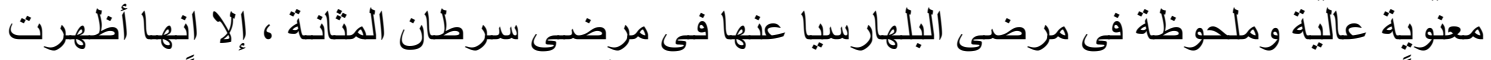

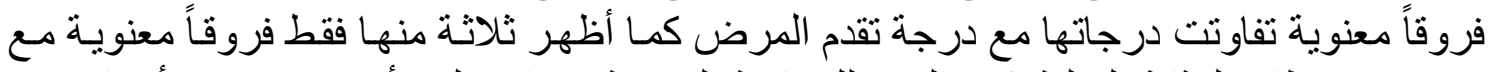
مرضى سرطان المثانة البولية ذات العقد الليمفاوية الموجبة بينما سجل دوفل الأرجنين 12 و الأسبار اجين

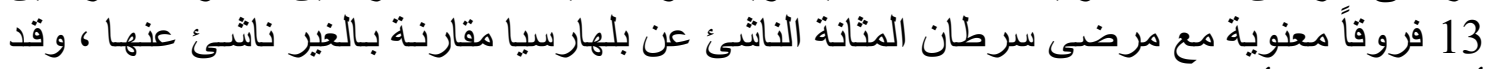

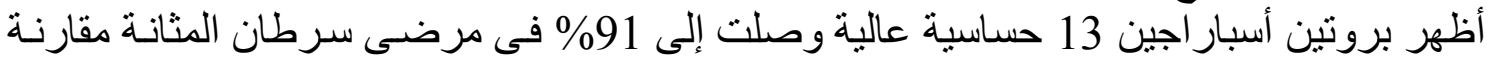

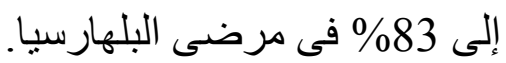

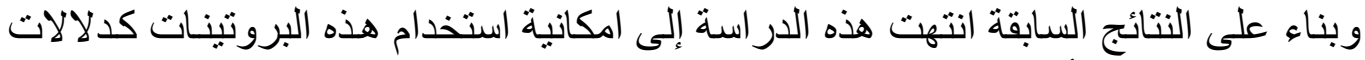

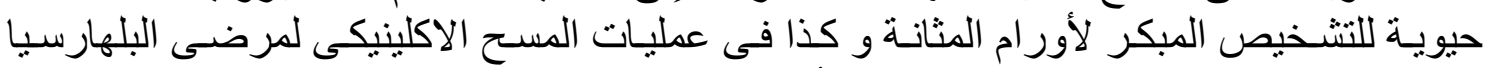

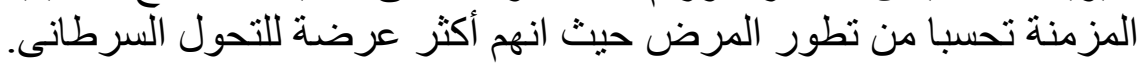

